\title{
Climate Change's Impacts on Weeds and Herbicide Efficacy: A Review
}

\author{
Amit Kumar* and Mukesh Kumar \\ Department of Agronomy, CCS Haryana Agricultural University, Hisar-125004, Haryana, India \\ *Corresponding author
}

\section{A B S T R A C T}

Climate change is a natural and continuous process. But recent relatively rapid change in climate occurs due to anthropogenic activities which makes alarming attention because it contributes largely to global warming by affecting the greenhouse gases (GHGs) and aerosols. GHGs mainly $\mathrm{CO}_{2}$, methane, nitrous oxide CFC 11 , CFC12, HCFC22and HFC23 with different global warming potential accumulate in atmosphere and increase in concentration over time creating the so called "greenhouse effect". This effect can alters balance by transmitting incoming solar radiation but absorbing outgoing thermal radiation from surface. Atmospheric $\mathrm{CO}_{2}$ rose from 280 to $387 \mu \mathrm{molmol}^{-1}$ from 1750 to 2007 and expected to reach $600 \mu \mathrm{molmol}^{-1}$ by 2050 and global earth surface temperature is likely to rise in a range of 1.1 to $6.4^{\circ} \mathrm{C}$ during the 21 st century due to the rising $\mathrm{CO}_{2}$ concentration. Weeds are complex in nature and have significant negative effect on agriculture. Chemical

\section{Keywords}

Climate changes,

Natural process,

Greenhouse effect, Environment.

\section{Article Info}

Accepted:

26 August 2017

Available Online:

10 September 2017 weed control becomes major choice/tool because of its economic, easy to use, greater efficacy, due to scarcity of labour and time saving. Climate component viz., light, $\mathrm{CO}_{2}$, temperature, precipitation, humidity, wind, environmental stress etc. affect crop-weed competition and efficacy of applied herbicides. Light stimulates weed seed development and leaf shape. Light is the source of energy for photosynthesis and the rate of photosynthesis determines the rate of phloem translocation of assimilates and subsequent phloem translocation will increase the movement of foliar-applied systemic herbicides. Most crops are $\mathrm{C}_{3}$ and most weeds are $\mathrm{C}_{4}$, and hence weed competition will consequently decrease as $\mathrm{CO}_{2}$ increases, should not be viewed as universal axiom as there are four major $\mathrm{C}_{4}$ crops of economic importance (corn, pearlmillet, sorghum, and sugarcane), and their many important $\mathrm{C}_{3}$ weeds. Increasing $\mathrm{CO}_{2}$ concentration increases the starch concentration in tissue and reduces the protein content leads to less demand of amino acids synthesis which alters the efficacy of ALS inhibitors herbicides. High temperature shortens the growth phases, stimulate stomata conductance and lowers the viscosity of cuticular lipids leads to increase permeability and diffusion of herbicides through the cuticle. Warmer temperature also reduce uptake of herbicides due to rapid drying of droplets. Increasing temperatures may mean an expansion of weeds into higher latitudes or higher altitudes.. Increased cuticle thickness and leaf pubescence in response to drought, will also reduce herbicide entry into leaves. At higher humidity leaf retention time of herbicides mainly hydrophilic increases. Blowing wind may cause spray drift or dry up the spray droplet. So there is need to pay special attention and to study the impact of climate factors on weed life, crop-weed competition and herbicide efficacy so that adaptation and mitigation strategies can be developed for changing climate. 


\section{Introduction}

Climate change is continuous process; in past it occurred over hundred or thousand $s$ of years. But recent changes in climate make alarming attention because of its shift occurs only in a few decades. Climate change occurs due to natural and human activities. Anthropogenic activities contribute largely to global warming by affecting the amounts of greenhouse gases (GHGs) and aerosols (small particles). These emissions accumulate in Earth's atmosphere and increase in concentration over time, creating the so-called greenhouse effect, which can alter energy balance by transmitting incoming solar radiation but absorbing outgoing thermal radiation from the surface (Schneider, 1992).

Global warming accompanied by an increase in earth's mean temperature, change in frequency and distribution of precipitation, wind pattern, evapotranspiration, weather extremities such as drought, floods, severe storms and hurricanes (Roeckner, 1992). Atmospheric carbon dioxide $\left(\mathrm{CO}_{2}\right)$ has risen from 280 to $387 \mu \mathrm{mol} \mathrm{mol}{ }^{-1}$ from 1750 to 2007 , as a result of continuous anthropogenic activities; the $\mathrm{CO}_{2}$ concentration is expected to reach $600 \mu \mathrm{mol} \mathrm{mol}{ }^{-1}$ sometime around 2050 (IPCC, 2007). Climate models projected that the global earth surface temperature is likely to rise in a range of 1.1 to $6.4^{\circ} \mathrm{C}$ during the 21 st century due to the rising $\mathrm{CO}_{2}$ concentration (IPCC, 2004). In past 250 years, fossil fuels burning change in land use and agriculture are the major anthropogenic sources that have contributed to GHGs emissions. Shift to modern agriculture is main driving forces contributing about $30 \%$ of greenhouse gas emissions (Nitze et al., 2008). $\mathrm{CO}_{2}$, methane, and nitrous oxide are the three primary greenhouse gases produced from agricultural sources.

These local and global shifts in climate have started affecting life on earth in number of ways as well as on food supply by its direct and indirect effect on agriculture. It can be greatest threats to sustain life in coming time. Achieving sustainable production in this changing unpredictable environment, need a holistic approach that focus on not only increasing crop productivity but also evolving strategies for effective pest management particularly weeds.

Weeds are complex in nature and these unwanted plants have significantly negative effect on agriculture, forestry, public health so on. Unlike other random and irregular diseases, insects, pests weeds are relatively constant and pose severe problems in crop production. Yield reduction due to weeds differs accordingly weed spp., crop and management practices. When weed emerges in high density, crop losses due to competition will be highest. Also they contaminate the crop seed and deteriorate quality of produce. Harvesting operation also affected by weeds. They produce allelochemicals and are host the insects-pest and diseases (Boydston et al., 2008). Hence weed control is must and major component for successful crop production. Weed can be managed by cultural, mechanical, biological and chemical methods. Chemical controls by herbicides is becomes the major choice/ tool because of its economic, easy to use, greater efficacy, due to scarcity of labours and time saving (McErlich and Boydston, 2013). Weeds compete for light, space, nutrients and moisture. The dynamics of competition between crops and weeds are affected by environmental conditions, and have been shown to change with $\mathrm{CO}_{2}$ enrichment. Differential responses of $\mathrm{C}_{3}$ and $\mathrm{C}_{4}$ plants to elevated $\mathrm{CO}_{2}$ and temperature may cause shifts in their competitive interactions.

Studies were done on impact of climate change on crop production. But less attention is given to importance of weed management particularly herbicide efficacy and its 
subsequent effects on the development of herbicides resisting weeds. Herbicides efficacy changes due to environmental stress and could have severe consequence for cropweed competition and may contributes to loss in production. To study the impact of climate change on herbicides efficiency it is important to understand how environmental conditions affect herbicides performance. Environmental conditions also affect interaction between plant and herbicides. Factors like light, $\mathrm{CO}_{2}$, temperature, moisture, relative humidity, rainfall and wind can affects herbicides efficiency by altering the penetration and translocation of herbicides in target plant or indirectly by changing the growth and physiological characteristics of the plants.

Change in climate can affect agriculture through increase in $\mathrm{CO}_{2}$ concentration, rise in temperature, variation in precipitation and solar radiation and weather extremities like drought, flood, storms etc. Increase $\mathrm{CO}_{2}$ concentration has beneficial effects on $\mathrm{C} 3$ plants, but only when other growth limiting factors are at optimum level. Beneficial effect of $\mathrm{CO}_{2}$ rise can be limit by rise in temperature for example there is no elevated $\mathrm{CO}_{2}$ effect on $\mathrm{C}_{3}$ Beans, peanut and $\mathrm{C}_{4}$ (grain sorghum). Increase in both $\mathrm{CO}_{2}$ and temperature may induce faster growth in determinant crops like cereals by stimulating photosynthesis and vegetative growth.

In $\mathrm{C}_{3}$ photosynthetic pathway, $\mathrm{CO}_{2}$ is first accepted by a sugar, Ribulose phosphate (RuBP) and Ribulose bisphosphate carboxylase catalyzed this reaction. Because of the dual activity of Rubisco (carboxylation and oxygenation), both $\mathrm{CO}_{2}$ and $\mathrm{O}_{2}$ compete for the same site on Rubisco, resulting in a 20-60\% loss of substrate (carbon) through photorespiration (oxygenation) (Bowes, 1996). Increase $\mathrm{CO}_{2}$ stimulate carboxylation, thereby reduces the losses of $\mathrm{CO}_{2}$ by photorespiration. On the other hand $\mathrm{C}_{4}$ have alternate $\mathrm{CO}_{2}$ fixation mechanism. $\mathrm{CO}_{2}$ initially fixed in mesophyll cells by phosphoenolpyruvate carboxylase (PEPcase), which has a higher affinity for $\mathrm{CO}_{2}$ than rubisco. The resultant 4-carbon organic acid formed in this reaction regenerates $\mathrm{CO}_{2}$ in the bundle sheath cells for fixation by Rubisco. Because of this internal mechanism photorespiration is inhibited.

Responses of weeds and crops to increasing $\mathrm{CO}_{2}$ levels were species-specific. Herbicide efficacy can be negatively affected by elevated $\mathrm{CO}_{2}$ and effects were dependent on the mode of action of herbicides, on weed species and on competition. Differential response of $\mathrm{C}_{3}$ and $\mathrm{C}_{4}$ plants to elevated $\mathrm{CO}_{2}$ and temperature can have important implications on crop-weed competition as most of the weeds are $\mathrm{C}_{4}$. But this fundamental idea that most crops are $\mathrm{C}_{3}$ and most weeds are $\mathrm{C}_{4}$, and hence weed competition will consequently decrease as $\mathrm{CO}_{2}$ increases, should not be viewed as universal axiom (Ziska 2001, 2003). Clearly, there are four major $\mathrm{C}_{4}$ crops of economic importance (corn, pearlmillet, sorghum, and sugarcane), and many important $\mathrm{C}_{3}$ weeds (e.g. Chenopodium album, Avena ludoviciana, Phalaris minor, Eclipta prostrate, Ammania baccifera etc.). Therefore, it is important to examine cropweed competition case by case to develop effective weed management practice for the emerging species in the changing climate scenario.

\section{Effect of light}

Light is one of the most influencing environmental factors for plant growth and development. Variation in light intensities changes the anatomy, morphology, and growth of plants, which further affects herbicide performance. Light is the source of energy for photosynthesis, and the rate of 
photosynthesis determines the rate of phloem translocation of assimilates. As light intensity increases Net photosynthetic rate also increases and higher photosynthesis and subsequent phloem translocation will increase the movement of foliar-applied systemic herbicides; for example, the efficacy of clethodim and tralkoxydim was reduced in ultraviolet light, which indicates that spraying these grass herbicides later in the day when light intensity is higher may improve their efficacy (McMullan, 1996). Suspended particulate matter in environment due to climate change may cause global dimming effect which interfere the incoming solar radiation. Sunlight degrades some preemergence herbicides on the soil surface, and if optimum moisture does not become available within a week after application, poor weed control often results. Light stimulates weed seed development and the brightness and amount of light influences leaf shape.

\section{Effect of elevated $\mathrm{CO}_{2}$ concentration}

Increase $\mathrm{CO}_{2}$ concentration increases starch concentration in tissue reduces protein content (Bowes, 1996). Less protein concentration leads to less demand of amino acids synthesis which alters the efficacy of ALS inhibitors herbicides. Elevated $\mathrm{CO}_{2}$ concentration and temperature alter the photosynthetic activity in plants which may subsequently affect the herbicide activity. Ziska et al., (2004) reported increased growth and root: shoot of field-grown Canada thistle (C. arvense) under elevated $\mathrm{CO}_{2}$ levels, which resulted in the reduced efficacy of glyphosate because of the dilution effect caused by large stimulation of below-ground growth. Climate change has shown to reduce plant available nitrogen through elevated $\mathrm{CO}_{2}$ (Williams et al., 2001; Zhang et al., 2005). The carbon nitrogen ratio of leaves is usually increased under $\mathrm{CO}_{2}$ enrichment. Availability of nutrients such as nitrogen and phosphorus appears to quickly become limiting, even when carbon availability is removed as a constraint, on plant growth when ambient $\mathrm{CO}_{2}$ concentrations are sufficiently increased (Hall and Allen Jr., 1993).

Therefore, unlike in $\mathrm{C}_{3}$ plants, increased $\mathrm{CO}_{2}$ concentrations will have less of an effect on the net photosynthetic rates of $\mathrm{C}_{4}$ plants. In $\mathrm{C}_{3}$ plants, temperatures above $25^{\circ} \mathrm{C}$ increase photorespiration and inhibit $\mathrm{CO}_{2}$ assimilation (Jordan and Ogren, 1984). Increase in temperature has little effect on $\mathrm{CO}_{2}$ assimilation in $\mathrm{C}_{4}$ plants because $\mathrm{CO}_{2}$ pumps in mesophyll cells maintain low photorespiration rates at all temperature.

Hence, $\mathrm{C}_{4}$ better adapted to heat stress and most of the weeds are $\mathrm{C}_{4}$ plants and they get competitive advantages over crop plant under stress condition.

Climate change may bring changes in weed population and in their phenology. Many weed species may expand their range and spread to new areas. In addition to its impact on agricultural weed, literature suggest that invasive species may become more of a threat in changing climate because of their strong response to elevated $\mathrm{CO}_{2}$ and changing climate compared to other native species (Singh et al., 2016). Higher photosynthesis rate at elevated $\mathrm{CO}_{2}$ in $\mathrm{C}_{3}$ plants (rice, wheat) mean they response more favorably to higher $\mathrm{CO}_{2}$ level than $\mathrm{C}_{4}$ weeds. Relative yield of $\mathrm{C}_{3}$ crops are higher than $\mathrm{C}_{4}$ crops due to rise in $\mathrm{CO}_{2}$ concentration. Alberto, 1996 studies the interaction between $\mathrm{CO}_{2}$ and temperature on barnyard grass-rice completion and reported that elevated $\mathrm{CO}_{2}$ concentration favorers crop at day/night temperature $27 / 21^{\circ} \mathrm{C}$ but favours growth of barnyard grass at $37 / 29^{\circ} \mathrm{C}$. At elevated $\mathrm{CO}_{2}$ NPK nutrient concentration in tissue found greater in rice than barnyard grass which enhance tillering, LAI, and net assimilation rate of rice. 


\section{Effect of temperature}

High temperature shortens the growth phase and grain filling duration through pollen sterility, lowering test weight and poor anthesis (Kadam et al., 2014). Temperature causes direct and indirect effect on herbicides efficiency. Higher temperature stimulate stomata conductance, lowers the viscosity of cuticular lipids leads to increase permeability and diffusion of herbicides through the cuticle; for example, uptake and translocation of ${ }^{14} \mathrm{C}$-glyphosate was found to be higher at $22^{\circ} \mathrm{C}$ than at $16^{\circ} \mathrm{C}$ in Desmodium tortuosum (Sharma and Singh, 2001). Similarly, Roundup Ready Soybean translocate more ${ }^{14} \mathrm{C}$-glyphosate to meristematic tissues at $35^{\circ} \mathrm{C}$ than at $15^{\circ} \mathrm{C}$, indicating potentially increased glyphosate injury at higher temperatures (Pline et al., 1999). Warmer temperature also reduce uptake of herbicides due to rapid drying of droplets.

Increasing temperatures may mean an expansion of weeds into higher latitudes or higher altitudes. Very aggressive weeds that are currently found in the south are limited in the northern states by low temperatures. Many $\mathrm{C}_{4}$ grass weeds are serious problems in the southern U.S. but do not occur at problem levels in the U.S. cornbelt. Studies have shown that itchgrass, a profusely tillering, robust grass weed could invade the central Midwest and California with only a $3^{\circ}$ warming trend (Patterson, 1995). Witchweed, a root parasite of corn, is limited at this time to the coastal plain of North and South Carolina. With an increase of temperature of $3^{\circ}$ it is speculated that this parasite could become established in the Corn Belt with disastrous consequences. The current distribution of both Japanese honeysuckle and kudzu is limited by low winter temperatures. Global Warming could extend their northern limits by several hundred miles. Similarly, under warmer conditions, Setaria viridis (L.)
P. Beauv. Germinated later in the (August) season (Dekker, 2003). This was a beneficial temporal non-synchrony with emergence of a maize crop, avoiding crop-weed competition. In contrast, a recent study indicated that this species would be a problematic weed in maize-based cropping systems elsewhere, through synchrony with maize emergence, which is probably due to stimulation by increased temperature (Peters and Gerowitt, 2014).

\section{Effect of precipitation}

Climate change alters the frequency and intensity of rainfall. Precipitation after application of herbicides can wash out the herbicides and reduces efficiency. Moisture is needed for weed seed germination. So weed adaption to these stress have more competitive advantages over crops. Increased rainfall frequency and intensity will have an adverse effect on uptake, retention, and activity of soil-applied herbicides (Bailey, 2004; Rodenburg et al., 2011). Increased cuticle thickness and leaf pubescence in response to drought, will reduce herbicide entry into leaves (Patterson, 1995). Lower precipitation amounts throughout the season may result in water stress conditions that affect both plant growth and herbicide efficacy (Zanatta et al., 2008). Increases environmental stress on crops may make them more vulnerable to attack by insects and plant pathogens and less competitive with weeds (Patterson, 1995). Pereira et al., (2011) found that the efficacy of sethoxydim was lower in goosegrass (E. indica) plants grown under water-deficit conditions. Similarly, plantain signalgrass (Urochloa plantaginea) plants grown under water stress were not effectively controlled by ACCase-inhibiting herbicides when applied during the later growth stages (Pereira, 2010). $\mathrm{C}_{3}$ plants are dominant in submerged soils; $\mathrm{C}_{4}$ plants are dominant in dry land soils. Submergence protects rice 
plants from severe competition with $\mathrm{C}_{4}$ weeds. On the other hand, upland rice and rainfed lowland rice with limited precipitation face severe competition with $\mathrm{C}_{4}$ weeds (Matsunaka, 1983).

\section{Effect of environmental stress}

Under imposed drought, Patterson (1986) found that $\mathrm{CO}_{2}$ enrichment reduced the effects of water stress and significantly increased leaf area and total dry weight of the three $\mathrm{C}_{4}$ grasses: Echinochloa crus-galli, Eleusine indica and Digitaria ciliaris. He concluded that $\mathrm{CO}_{2}$ enrichment can increase the growth of both $\mathrm{C}_{3}$ and $\mathrm{C}_{4}$ plants under water stress, but growth stimulation can be expected to be greater in $\mathrm{C}_{3}$ plants. Carlson and Bazzaz (1980) reported that doubling the $\mathrm{CO}_{2}$ concentration from 300 to $600 \mathrm{ppm}$ increased WUE by $55 \%$ in sunflower, $54 \%$ in corn, $48 \%$ in soybean, $128 \%$ in common ragweed, $87 \%$ in velvetleaf, $84 \%$ in jimson weed and $76 \%$ in redroot pigweed. They speculated that the greater stimulation of WUE in the weeds than in the crops might convey a competitive advantage to the weeds. Chauhan and Abugho (2013), found that rice could not survive under water stress conditions. By contrast, Amaranthus spinosus and Leptochloa chinensis (L) survived under water stress conditions and produced a significant number of tillers/branches and leaves even at the lowest soil water content. $\mathrm{C}_{4}$ plants have higher nutrient use efficiencies than $\mathrm{C}_{3}$ grasses, and reduced nitrogen availability has been shown to benefit $\mathrm{C}_{4}$ plants over $\mathrm{C}_{3}$ plants in tall grass prairie (Bleier and Jackson, 2007).

\section{Effect of relative humidity and wind}

At high humidity, leaf retention time increases mean more penetration. Relative humidity primarily influences the activity of foliar-applied herbicides through its effects on herbicide uptake. Relative humidity could influence the efficacy of foliar-applied herbicides through interactions between the herbicide droplet, leaf cuticle, and availability of water in or around droplets (Devine et al., 1993). Effect of humidity was higher on hydrophilic herbicides than lipophilic herbicides. Spray droplets dry up due to wind blowing so reduces efficiency. Can interfere with surface application and cause spray drift, thereby reducing spray application efficiency (Combellack, 1982).

Given the importance to herbicide use, it is essential to understand the factors that governs herbicides performance. Successful management not only depends on chemical properties of herbicides used but also on its interaction with the plant and surrounding environments. Herbicides absorption by target plant largely depends on its interaction with atmosphere, soil or soil-atmosphere interface. Foliar applied herbicides are influenced by many environment factors but soil applied herbicides are influenced mainly by soil moisture and temperature. Herbicides efficacy affected by environment factors such as temperature, moisture, relative humidity and solar radiation plant's physiology and its susceptibility to herbicides. Interactions between all these factors further complicate the precise determination of their effects on herbicides performance. Climate change has impact on photosynthesis process that affects herbicides absorption, translocation and metabolism. For example, at low rates, diclofop toxicity to wild oat was higher at a lower temperature $\left(10^{\circ} \mathrm{C}\right)$ than at a higher temperature $\left(24^{\circ} \mathrm{C}\right)$ (Mulder and Nalewaja, 1978). Plant growth and herbicides performance is significantly affected by change in global climate due to rise in $\mathrm{CO}_{2}$ concentration and its impact on temperature rise and precipitation. Knowing the effect of climate change on weed growth and herbicides activity is needed to optimize 
herbicide application for better weed management in coming days.

So, there is a need to evaluate the effect of changing climate on weed flora, crop-weed competition, herbicide efficacy so that adaptation and mitigation strategies can be developed accordingly. Information generated from these studies will help in identifying the potential of weed control measures under a range of atmospheric and edaphic conditions.

\section{References}

Alberto, A.M., Ziska, L.H., Cervancia, C.R., Manalo, P.A., 1996. The influence of increasing carbon dioxide and temperature on competitive interactions between a C4 crop, rice (Oryza sativa), and a C3 weed (Echinochloa glabrescens). Aust. J. Plant Physiol. 23, 793-802.

Bailey, S. W., 2004. Climate change and decreasing herbicide persistence. Pest Manage. Sci. 60, 158-162. doi: 10.1002/ps.785

Bleier, J. S., and R. D. Jackson. 2007. Manipulating the quantity, quality and manner of $\mathrm{C}$ addition to reduce soil inorganic $\mathrm{N}$ and increase C4: C3 grass biomass. Restoration Ecol. 15: 688-695.

Bowes, G., 1996. Photosynthetic responses to changing atmospheric carbon dioxide. In: Baker, N.R. (Ed.), Photosynthesis and the Environment. Advances in Photosynthesis, vol. 5. Kluwer, Dordrecht, pp. 387-407.

Boydston, R.A., Mojtahedi, H., Crosslin, J.M., Brown, C.R., Anderson, T., 2008. Effect of hairy night shade (Solanum sarrachoides) presence on potato nematodes, diseases, and insect pests. Weed Sci. 56, 151-154.

Carlson, R. W., and F. A. Bazzaz. 1980. The effects of elevated $\mathrm{CO} 2$ concentrations on growth, photosynehesis, transpiration and water use efficiency of plants. In: Environmental and Climatic Impact of Coal Utilization, J. J. Singh and A. Deepak (Eds.). Academic Press, New York. pp. 610-622.

Chauhan, B. S., and Abugho, S. B. 2013. Effect of water stress on the growth and development of Amaranthus spinosus, Leptochloa chinensis, and rice. Am. J. Plant Sci. 4, 989998.

Combellack, J.H., 1982. Loss of herbicides from ground sprayers. Weed Res. 22, 193-204.

Dekker, J., 2003. "Evolutionary biology of the Foxtail (Setaria) species-group," in Weed Biology and Management, ed. Inderjit (Dordrecht: Kluwer Academic Publishers), 65-114.

Devine, M.D., Duke, S.O., Fedtke, C., 1993. Foliar Absorption of Herbicides. PrenticeHall, Englewood Cliffs, NJ pp. 29-52.

Hall, A. E. and L. H. Allen Jr. 1993. Designing cultivars for the climatic conditions of the next century. In: International Crop Science I, D. R. Buxton, R.Shibles, R. A. Forsberg, B. L. Blad, K. H. Asay, G. M. Paulsen and R. F. Wilson (eds.). Crop Science Society of America, Madison, Wisconsin. pp. 291-297.

IPCC, 2004. Intergovernmental Panel on Climate Change, IPCC Fourth Assessment Report: Climate Change 2007 (AR4). http:// www.ipcc.ch

IPCC, 2007. Assessment Report. http://www.ipcc.ch/pdf/assessmentreport/ar4/syr/ar4_syr_spm.pdf

Jordan, D.B., and Ogren, W.L., 1984. The CO2/O2 specificity of ribulose 1, 5-bisphosphate carboxylase/oxygenase. Planta 161, 308-313.

Kadam, N.N., Xiao, G., Melgar, R.J., Bahuguna, R.N., Quinones, C., Tamilselvan, A., Prasad, P.V.V., Jagadish, S.V.K., 2014. Agronomic and physiological response to high temperature, drought, and elevated $\mathrm{CO} 2$ interaction in cereals. Adv. Agron. 127, 111156.

Matsunaka, S., 1983. Evolution of rice weed control practices and research: world perspective. In: Weed Control in Rice. IRRI, P. O. Box 933, Manila, Philippines. pp. 5-18.

McErlich, A.F., Boydston, R.A., 2013. Current state of weed management in organic and conventional cropping systems. Publications from USDA-ARS/UNL Faculty. Paper 1387.

McMullan, P.M., 1996. Grass herbicide efficacy as influenced by adjuvant, spray solution $\mathrm{pH}$, and ultraviolet light. Weed Technol. 10, 7277.

Mulder, C.E.G., Nalewaja, J.D., 1978. Temperature effect of phytotoxicity of soil- 
applied herbicides. Weed Sci. 26, 566-570.

Nitze, W.A., Topping, J.C., Goldberg, M., Devic, M., Schultz, E., 2008. Reducing our food's impact on climate change. Clim. Alert. 18, 6.

Patterson, D. T., 1985. Comparative ecophysiology of weeds. In: Weed Physiology: Reproduction and Ecophysiology, S. O. Duke (Ed.). CRC Press, Inc. Boca Raton, Florida. pp. 101-132.

Patterson, D.T., 1995. Weeds in a changing climate. Weed Science, 43, 685-701.

Pereira, M.R.R., 2010. Efeito de herbicidas sobre plantas de Brachiaria plantaginea submetidas a estresse hi'drico. Planta Daninha 28, $1047-$ 1058.

Pereira, M.R.R., Souza, G.S.F., Martins, D., Melhoranc, a Filho, A.L., Klar, A.E., 2011. Respostas de plantas de Eleusine indica sob diferentes condic, ões hi'dricas a herbicidas inibidores da ACCase. Planta Daninha 29, 397-404.

Peters, K., Breitsameter, L., and Gerowitt, B. 2014. Impact of climate change on weeds in agriculture: a review. Agron. Sustain. Dev. 34, 707-721.

Pline, W.A., Wu, J., Hatzios, K.K., 1999. Effects of temperature and chemical additives on the response of transgenic herbicide-resistant soybeans to glufosinate and glyphosate applications. Pestic. Biochem. Physiol. 65, 119-131.)

Rodenburg, J., Meinke, H., Johnson, D.E., 2011. Challenges for weed management in African rice systems in a changing climate. J. Agric. Sci. 149, 427-435.

Roeckner, E., 1992. Past, present and future levels of greenhouse gases in the atmosphere andmodel projections of related climatic changes. J. Exp. Bot. 43, 1097-1109.
Schneider, S.H., 1992. The climatic response to greenhouse gases. Adv. Ecol. Res. 22, 1-32.

Sharma, S.D., Singh, M., 2001. Environmental factors affecting absorption and bio-efficacy of glyphosate in Florida beggarweed (Desmodium tortuosum). Crop Prot. 20, 511516.

Singh, Mool Chand, Dubey, S.C. and Yaduraju, N.T., 2016. Climate change and its possible impacts on weeds. International Journal of Science, Environment and Technology, Vol. 5, No 3, 1530 - 1539.

Williams, M. A., C.W. Rice and C. E. Owensby. 2001. Nitrogen competition in a tall grass prairie ecosystem exposed to elevated carbon dioxide. Soil Sci. Soc. Amer. J. 65: 340-346.

Zanatta, J.F., et al., 2008. Teores de a'gua no solo e efica'cia do herbicida fomesafen no controle de Amaranthus hybridus. Planta Daninha 26, 143-155.

Zhang, W., K. M. Parker, Y. Luo, S. Wan, L. L. Wallace and S. Hu. 2005. Soil microbial responses to experimental warming and clipping in a tall grass prairie. Global Change Biol. 11: 266-277.

Ziska, L.H., George, K., 2004. Rising carbon dioxide and invasive, noxious plants: potential threats and consequences. World Resour. Rev. 16, 427-447.

Ziska, L.W., 2001,"Changes in competitive ability between a C4 crop and a C3 weed with elevated carbon dioxide", Weed Science, 49, 622-627.

Ziska, L.W., 2003,"Evaluation of yield losss in field sorghum from a C3 and C4 weeds with increasing CO2", Weed Science, 51, 914-918.

\section{How to cite this article:}

Amit Kumar and Mukesh Kumar. 2017. Climate Change's Impacts on Weeds and Herbicide Efficacy: A Review. Int.J.Curr.Microbiol.App.Sci. 6(9): 2846-2853.

doi: https://doi.org/10.20546/ijcmas.2017.609.349 